\section{Dust Content and Visibility in Dust Storms}

AN article by W. S. Chepil and N. P. Woodruff on sedimentary characteristics of dust storms and dust concentration, published in the American Journal of Science (255, February 1957), gives numerical data for a subject on which little similar information is available, but which is of considerable importance to the design of machinery for operation in arid regions. The authors caught dust at heights of from 4 to $20 \mathrm{ft}$. in lorry-borne apparatus in dust storms in Kansas and Colorado, in the United States. At the same time and on clear sunny days only, they made visibility observations, using dark visibility objects, and also measured the wind speed. From their work they are able to give numerical rules for the variation of dust density with height, and extrapolating upwards with an exponential relation, total atmospheric dust content, visibility and dust content, and the amount of dust transported through a vertical square mile. The extrapolation to a height of one mile from observations to only $20 \mathrm{ft}$. may be subject to considerable error. The authors give some justification for it from the work of Wilhelm Schmidt ("Massenaustausch in freier Luft", 1925). Their figures give a vivid impression of the meaning of the term 'dust bowl'. The relation found between visibility $V$ (in miles) and dust concentration is $V=0.9 C_{a}-0.8$, where $C_{a}$ is the concentration of dust at a height of $6 \mathrm{ft}$. in $\mathrm{mgm} . / \mathrm{ft}^{3}$. Details are given of some dust storms ranging from one with a dust concentration at $6 \mathrm{ft}$. of $0.09 \mathrm{mgm}$. $/ \mathrm{ft}^{3}$, visibility $4.8 \mathrm{miles}$, and an average rate of soil removal 53 tons/hr./vertical sq. mile, to one with corresponding values of $37.6 \mathrm{mgm}$./ $\mathrm{ft}^{3}, 0.05$ miles and 47,951 tons/hr./vertical sq. mile. The values for an average storm are concentration $6.54 \mathrm{mgm} . / \mathrm{ft}^{3}$, visibility 0.93 miles and rate of soil removal 9,945 tons/hr./vertical sq. mile.

\section{Level of the Caspian Sea}

During the past twenty-five years the level of the Caspian Sea has fallen by $2 \frac{1}{2}$ metres, and this is affecting shipping, fisheries, petroleum winning and salt deposition in Kara-Boghaz-Gol. Recently, a conference on this subject, organized by the Academy of Sciences of the U.S.S.R., took place in Astrakhan. Prof. B. A. Apolov gave a summary report in which he said that the lowering of the level of the Caspian Sea is due to the warming up of the climate of the northern hemisphere and to the increased utilization of the rivers of the region for irrigation and water supplies. He estimates that by 1970 the level may have fallen another metre. To remedy this, he proposed the construction of a dam in the northerm part of the Caspian Sea. Other proposals (Dvorov, I. M., Priroda, No. 1,$111 ; 1957)$ included the diversion of the upper courses of Onega, Northern Dvina and Pechora Rivers into the Volga, or the diversion of the Siberian rivers into the Caspian Sea.

Royal Military College of Science, Shrivenham: Studentships

The War Office and Ministry of Supply announce that the following have been awarded civilian studentships, tenable for three years, at the Royal Military College of Science, Shrivenham: J. H. Garvie (Glasgow Academy), G. H. Gregg (Cockburn High School, Leeds), D. A. G. Pedder (Admiralty) and K. R. Thomas (Redruth County Grammar School). These studentships are sponsored by the Ministry of Supply on behalf of all the Government departments employing scientists. Their object is to give to young men who intend to enter the Scientific Civil Service a university education in science or engineering. To this end, the War Office makes available some places on the Young Officers' Degree Course at the Royal Military College of Science, Shrivenham. On these courses students are prepared for the University of London degree of B.Sc. (Special) in chemistry, physics or mathematics or B.Sc. (Engineering). In addition to a first-class education in science or engineering, the Royal Military College of Science provides a useful background education for the study of defence research problems so that the courses at the College are particularly suitable for training young scientific officers for work in Government defence research establishments.

Supply of Scientists and Technologists for Industry

A CONFERENCE on "The Supply of Scientists and Technologists for Industry", under the auspices of the British Association, will be held in the University of Leeds on July 5. The conference has been arranged in connexion with the Report of the Science and Industry Committee, published by the Oxford University Press on May 31, under the title of "Industry and Technical Progress", by Prof. C. F. Carter and Prof. B. R. Williams, the directors of the two research units appointed by the Committee. The conference will discuss Chapter 9 of this report, which is devoted to a consideration of some of the problems connected with increasing the supply of trained men and women for industry. These include certain problems confronting the schools, colleges and universities, such as early leaving, early specialization, university entrance requirements, the type of university degrees, and the recruiting of science teachers for schools and staff for the technical colleges. Some of the problems confronting industry are also to be discussed, including the qualities industry looks for in a scientist or technician, the shortage of scientific staff, salaries, chances of promotion, training schemes in firms, recruitment by large and small firms, efficiency in the use of scientists and technologists by industry, and the shortage of draughtsmen. 'The conference is open to all who are interested in this subject, without fee. Applications for tickets should be addressed to the Secretary, British Association, Burlington House, Piccadilly, London, W.1.

\section{Electronics Course at Harwell}

The twelfth specialized course on the design, use and maintenance of electronic instruments used in nuclear physics, radiochemistry and in work with radioactive isotopes will be held in the Reactor School, Atomic Energy Research Establishment, Harwell, during July 15-19. The course will include lectures, demonstrations and practical work on many types of electronic instruments, including counters, d.c. and pulse amplifiers, scalers and rate meters. The course is intended primarily for physicists and electronic engineers : the fee for the course is 25 guineas, which does not include the cost of accommodation in the district, but local accommodation can be arranged on request. Since the number of places on the course are limited, application forms should be returned as soon as possible, and in any case before June 21. Application forms and further information can be obtained from the Divisional Administration Officer, Electronics Division, Atomic Energy Research Establishment, Harwell, Nr. Didcot, Berkshire. 